\title{
РЕАЛІЗАЦІЯ ПРОДУКТИВНОГО ПОТЕНЦІАЛУ МОЛОЧНОЇ ПРОДУКТИВНОСТІ ПЕРВІСТОК НА ПРОМИСЛОВОМУ КОМПЛЕКСІ
}

\author{
Капшук Наталя Олексіївна \\ асистент \\ Дніпровський державний аграрно-економічний університет \\ ORCID: 0000-0002-2859-2795 \\ Email: kapshuk-1990@ukr.net
}

\begin{abstract}
В статті відображено результати досліджень на предмет прояву генетичного потенціалу молочного продуктивності голштинських первісток, народжених від матерів у першу, другу, третю та четверту лактації в умовах з повним дотриманням правил гуманного поводження та ветеринарно-санітарних норм на тваринницькому комплексі Приватного акиіонерного товариства "Арго-Союз" Синельниківського району Дніпропетровської області. Продуктивні якості піддослідних тварин характеризували за показниками живої маси (ка), тривалості лактації (днів), показниками удою за весь лактаційний період, та за 305 днів лактації (кг) фізичного та 4-\% молока. Так, тривалість лактаційного періоду тварин усіх піддослідних груп довша за значення референційованої лактації (305 діб). Найтриваліший продуктивний період був у тварин, народжених від первісток - 573 доби. Функиіональна активність організму піддослідних тварин, чотирьох дослідних груп визначалася за показниками найвищого добового удою за повну лактацію (ке), показник кількості фізичного та в перерахунку на 4 \%-не молоко отриманого на одну добу за лактацію та за 305 днів лактації (к2), а також кількість молока отриманого на 1 кг живої маси в перерахунку на 4 \%-не молоко за повну та за 305 діб лактації (кг). Так, найвищим добовим удоєм (45 ке) характеризуються дочки-первістки, народжені від матерів четвертої лактації, що на 5 ке молока більше, ніж показник добового удою тварин інших піддослідних груп. Характеризуючи якісний склад молока корів-дочок голштинської породи у першу лактацію, отриманих від корів різного віку необхідно відмітити, що він повністю відповідав породним особливостям, так масова частка жиру та білку була на високому рівні коливалась в межах 3,80-3,84 \% та 3,17-3,21 \% відповідно. Показник продукції молочного жиру та білку в них становив 427,89-581,57 ке та 358,39-484,31 ке відповідно. Встановлено, що за показниками удою повної лактації та у перерахунку на 305 днів, тривалості продуктивного періоду, функиіональної активності організму та якісними характеристиками молочної продукції більш продуктивними і стабільними виявились первістки, народжені від матері четвертої лактації. Натомість, первістки, отримані від корів другої лактації показали найнижче значення вищеперерахованих показників.
\end{abstract}

Ключові слова: первістка, лактація, удій, жир, білок.

DOI: https://doi.org/10.32845/bsnau.lvst.2019.4.8

Продуктивне використання корів знаходяться в прямому зв'язку з біологічно можливим довголіттям кожної тварини. Тривалість господарського використання корів $\epsilon$ важливою господарсько-корисною ознакою, так як від неї залежить кількість отриманої продукції, величина і інтенсивність ремонту стада, а також рівень окупності витрат на утримання. Біологічно обумовлена тривалість продуктивного періоду великої рогатої худоби знаходиться в межах 12-17 лактацій. Однак у багатьох господарствах тривалість експлуатації становить 3-3,5 лактації, а високопродуктивних стадах не більше 3-х лактацій. Більшість корів не доживає до 4-6 лактацій, коли у них проявляється найвища продуктивність. Висока молочна продуктивність тварин, низькі витрати кормів і швидка окупність вирощування корів можливі при збільшенні довічного удою, який досягається у корів 3 максимальною тривалістю господарського використання [1-7].

Багато вчених, зокрема Т.В. Підпала (2005), Ю.П. Полупан та Т.П. Коваль (2005), М.І.Гиль (2008), Л.М. Хмельничий та ін. (2014) [8-11] й інші вважають, що використання бугаїв-поліпшувачів впливає переважно на зміну господарсько-корисних ознак молочної худоби. У цей же час Ю.Ф. Мельник та ін. (2008) наголошують, що вплив матері нащадків досить складний, це і середовище ембріонального розвитку, і повноцінність та якість годівлі новонародженого, його сила імунітету, а також передача генетичного матеріалу яйцеклітиною [12]. Ось тому, зовсім не випадково, дослідженнями $€$ М. Зайцева (2017) встановлено, що від

високопродуктивних корів не завжди виростають кращі дочки, а від низькопродуктивних - гірші дочки. Більше того, спадкові якості матерів не завжди можуть проявлятися у наступному поколінні [13].

Із зарубіжних племінних ресурсів найбільша питома вага приходиться на корів голштинської породи. Ці тварини відрізняються високою молочною продуктивністю та хорошо адаптовані до умов промислової технології [14].

Мета роботи - встановити залежність рівня прояву генетичного потенціалу молочної продуктивності корів-дочок першої лактації, отриманих від матерів різного віку - першоїчетвертої лактації.

Матеріали та методи досліджень. Відібране поголів'я корів було ссрормоване у чотири групи: I група (n=35) - тварини народжені від корів-матерів у першу лактацію; II група ( $n=35)$ - тварини народжені від корів-матерів у другу лактацію; III група (n=35) - тварини народжені від корівматерів у третю лактацію; IV група ( $n=35)$ - тварини народжені від корів-матерів у четверту лактацію. Проте, вже першу лактацію з 35 голів відібраних первісток (I група) закінчило лактацію 34 голови, II групи - 33 голови, III (контрольної) групи - 33 голови та IV групи - 34 голови.

Результати дослідження. Добре відомо, що рівень молочної продуктивності корів визначається, у тому числі, їх живою масою. Чим вища маса корів, тим вища їх молочна продуктивність. Більше того, у даних дослідженнях показник живої маси первісток мав інформативне значення, оскільки вони були отримані від корів-матерів різного віку (табл. 1).

Вісник Сумського національного аграрного університету Серія «Тваринництво», випуск 4 (39), 2019 
Слід зазначити, що первістки II і III (контрольної) групи, матері яких були корови відповідно другої і третьої лактації, характеризувалися високою та практично однаковою живою масою, яка становила в середньому відповідно 588,6 і 583,8 кг. Лише дещо нижчим цим значенням відзначалися первістки IV групи, у яких жива маса становила у середньому 580,5 Кг.

Відносно найвищим показником живої маси відзначалися первістки I групи, які були отримані від матерівпервісток, і становила у середньому 591,6 кг, що було вище значення аналогів IV групи на $1,88 \%(P<0,05)$.

Таким чином, жива маса корів у першу лактацію, матері яких були різного віку, коливається в межах від 580,5 кг до 591,6 кг. Причому, первістки, матері яких були теж первістками показують найвищу живу масу. Вірогідно хороші умови вирощування ремонтного молодняку забезпечують високі показники живої маси у першу лактацію, що і забезпечує народження здорового та життєздатного потомства, тоді як матері старших лактацій дещо виснажуються інтенсивними умовами експлуатації, що і відображається на їх нащадках

Що стосується тривалості лактації, то нормою вважається - 305 діб. Чим вона коротша, тим швидше запліднюється тварина після отелення i, навпаки, чим триваліший період від отелення до запліднення, тим довший період лактації, що визначається ефективністю штучного осіменіння. Ось тому, за відповідних умов утримання та годівлі, молочна продуктивність буде тим вищою, чим триваліший період лактації.

Дослідження показали, що тривалість лактаційної функції первісток III (контрольної) групи, отриманих від матерів у третю лактацію, становила 492,8 доби. Цей показник був вище норми на 187,8 доби. У цей же час практично такою ж тривалістю лактації характеризувалися первістки IV групи, які були отриманні від матерів у четверту лактацію у яких вона продовжувалася 504,9 доби. Відносно наближеною до нормальної лактації характеризувались первістки ॥ групи, отриманні від матерів у другу лактацію, і становила у середньому 334,6 доби, що було менше показника тварин III (контрольної) групи на 47,28 \% (Р<0,001).

Таблиця 1

Продуктивні якості корів-дочок у першу лактацію, отриманих від матерів у різні лактації

\begin{tabular}{|c|c|c|c|c|c|c|}
\hline \multirow{3}{*}{$\begin{array}{c}\text { Група тварин за віком у } \\
\text { лактаціях }\end{array}$} & \multirow{3}{*}{$\begin{array}{l}\text { Жива } \\
\text { маса, кг }\end{array}$} & \multirow{3}{*}{$\begin{array}{l}\text { Лактація, } \\
\text { діб }\end{array}$} & \multicolumn{4}{|c|}{ Удій молока, кГ } \\
\hline & & & \multicolumn{2}{|c|}{ повна лактація } & \multicolumn{2}{|c|}{ лактація 305 діб } \\
\hline & & & фізичне молоко & те ж у $4 \%$-му & фізичне молоко & те ж у 4 \%-му \\
\hline I, $n=34$ & $\begin{array}{l}591,6 \\
\pm 3,47\end{array}$ & $\begin{array}{l}573,1^{* *} \\
\pm 8,91\end{array}$ & $\begin{array}{c}15058,9^{* * *} \\
\pm 398,87\end{array}$ & $\begin{array}{r}14580,0 \\
\pm 372,10\end{array}$ & $\begin{array}{l}10160,9 \\
\pm 307,97\end{array}$ & $\begin{array}{r}9844,9 \\
\pm 292,82\end{array}$ \\
\hline II, $n=33$ & $\begin{array}{l}588,6 \\
\pm 2,54\end{array}$ & $\begin{array}{l}334,6 \\
\pm 5,07\end{array}$ & $\begin{array}{l}11180,6 \\
\pm 421,97\end{array}$ & $\begin{array}{r}10890,6 \\
\pm 399,68\end{array}$ & $\begin{array}{r}10013,7 \\
\pm 175,30 \\
\end{array}$ & $\begin{array}{c}9757,4 \\
\pm 169,95 \\
\end{array}$ \\
\hline III (контрольна, n=33) & $\begin{array}{l}583,8 \\
\pm 3,44\end{array}$ & $\begin{array}{c}492,8 \\
\pm 22,53\end{array}$ & $\begin{array}{c}14423,8^{* * *} \\
\pm 662,96\end{array}$ & $\begin{array}{r}14059,3 \\
\pm 632,10\end{array}$ & $\begin{array}{l}10155,6 \\
\pm 265,49\end{array}$ & $\begin{array}{r}9907,0 \\
\pm 248,62\end{array}$ \\
\hline IV, $n=34$ & $\begin{array}{l}580,5 \\
\pm 3,75\end{array}$ & $\begin{array}{c}504,9 \\
\pm 22,56\end{array}$ & $\begin{array}{c}15237,1^{* * *} \\
\pm 636,34\end{array}$ & $\begin{array}{r}14818,3 \\
\pm 618,87\end{array}$ & $\begin{array}{c}11017,2^{* * *} \\
\pm 245,67\end{array}$ & $\begin{array}{r}10712,5 \\
\pm 236,88\end{array}$ \\
\hline
\end{tabular}

Найбільш тривалою була лактація у первісток I групи, отриманих від матерів у першу лактацію, і становить 573,1 доби, що перевищувало показник II (контрольної) групи на $14,01 \%(P<0,01)$, а піддослідних тварин II групи на $41,62 \%(P<0,001)$.

Отже, лактаційна функція піддослідних первісток, матері яких були різного віку, досить тривала. Причому, якщо у піддослідних корів III (контрольної) і IV групах вона тривала у середньому 492,8-504,9 доби, то у первісток II групи - 334,6 доби. Тварин І групи характеризуються найтривалішим лактаційним періодом, який становить у середньому 573,1 доби.

Характеризуючись різною тривалістю лактаційного періоду піддослідні первістки відзначалися різними показниками рівня молочної продуктивності. Відносно найнижчим показником удою за увесь лактаційний період характеризувалися первістки II групи, у яких він становив у середньому 11180,6 кг фізичного або 10890,6 кг 4 \%-ного молока. Натомість аналоги III (контрольної) групи мали ці показники відповідно на рівні 14423,8 і 14059,3 кг, що було вище значення тварин II групи відповідно на 22,49 \% (P<0,001) і 22,54 $\%(P<0,001)$, оскільки тривалість лактаційного періоду була довшою у 1,47 рази.

Досить високим показником молочної продуктивності характеризувалися первістки I групи, у яких удій становив в середньому 15058,9 кг фрізичного або 14580, 0 кг 4 \%-ного молока. Ці показники перевищували значення аналогів ॥ групи, у яких лактаційний період був коротшим у 1,71 разів, на $25,75 \%(\mathrm{P}<0,001)$ і $25,30 \%(\mathrm{P}<0,001)$, а у порівнянні 3 показниками III (контрольної) групи ця різниця становила відповідно 4,22 і 3,57 \%. Тобто, удій цих піддослідних первісток двох груп був практично рівним.

Найвищим показником продуктивності відзначалися первістки IV групи, від яких за увесь лактаційний період було отримано у середньому 15237,1 кг фрізичного або 14818,3кг 4 \%-ного молока. Якщо ці показники удою були практично рівними із значеннями аналогів I групи, то у порівнянні 3 тваринами II групи вони були вищими відповідно на 26,62 \% (P<0,001) і 26,51 \% (P<0,001), оскільки і тривалість лактації була довшою у 1,51 разів.

Таким чином, піддослідні голштинські первістки характеризуються досить високою молочною продуктивністю, рівень якої знаходиться у прямій залежності від тривалості лактаційного періоду.

Щоб дати об'єктивну характеристику продуктивного потенціалу піддослідних первісток, отриманих від корівматерів різного віку, необхідно порівняти їх удій в перерахунку на 305 діб лактації. Дослідження показали, що величина удою у цей період у повній мірі відповідала їх високому рівню генетичного потенціалу. Так, показник удою за цей період у первісток I, II і III (контрольної) груп був досить високим та практично рівним і становив у середньому 10013,7-10160,9 кг молока. При цьому, молочна продуктивність первісток IV групи знаходилася на рівні 11017,2 кг, 
що було вище значення аналогів I і III (контрольної) груп відповідно на 7,77 і 7,82 \% (P<0,05), а показника первісток II групи - на $9,11 \%(P<0,01)$.

Отже, дочки-первістки народжені у першу, другу та третю лактації корів-матерів удій за 305 діб лактації становить близько 10000 кг, тоді як у четверту - біля 11000 кг молока.

Характеризуючи піддослідних первісток чотирьох груп за показником удою упродовж 305 діб та в перерахунку на 4 \%-не молоко, необхідно відмітити, що міжгрупова різниця по удою молока практично була такою ж, як і у фізичному молоці. Так, молочна продуктивність IV групи була на рівні 10712,5 кг 4 \%-ного молока, що було вище значення тварин-аналогів I і II груп відповідно на 8,10 \% $(P<0,05)$ і 8,92 $\%(P<0,01)$, а показника первісток III (контрольної) групи - на
$7,52 \%(P<0,05)$.

Таким чином, піддослідні первістки характеризуються високим генетичним потенціалом продуктивності, який реалізується незалежно від віку їх матерів.

Значний рівень молочної продуктивності всіх піддослідних тварин у першу лактацію, отриманих від корів різного віку забезпечувала висока функціональна активність їх організму (табл. 2). Так, показник найвищого добового удою за повну лактацію у первісток I, II і III (контрольної) груп був досить високим та практично рівним і становив у середньому 40,1-40,4 кг молока. При цьому, найвищий добовий удій первісток IV групи, отриманих від матерів четвертої лактації був на рівні 45,1 кг, що було вище значення аналогів I і II груп відповідно на 10,42 і 11,09\% (P<0,01), а показника первісток III (контрольної) групи - на 10,64 \% (P<0,01).

Таблиця 2

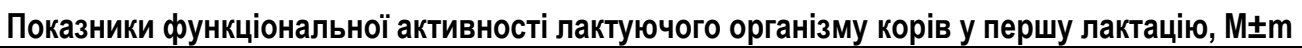

\begin{tabular}{|c|c|c|c|c|c|c|c|}
\hline \multirow[b]{3}{*}{$\begin{array}{c}\text { Група тварин за віком у } \\
\text { лактаціях }\end{array}$} & \multicolumn{7}{|c|}{ Секреція молока впродовж лактації: } \\
\hline & \multicolumn{4}{|c|}{ повної } & \multicolumn{3}{|c|}{ за 305 діб } \\
\hline & $\begin{array}{c}\text { Найвищий } \\
\text { добовий } \\
\text { удій, кг }\end{array}$ & на 1 добу, кг & $\begin{array}{c}\text { те ж у } \\
4 \text { \%-му молоці }\end{array}$ & $\begin{array}{c}\text { на } 1 \text { кг ж.м. } \\
4 \% \text {-го } \\
\text { молока, кг }\end{array}$ & на 1 добу, кг & $\begin{array}{c}\text { те ж у } \\
4 \text { \%-му } \\
\text { молоці }\end{array}$ & $\begin{array}{c}\text { на } 1 \text { кг ж. м. } 4 \text { \%- } \\
\text { го молока, кг }\end{array}$ \\
\hline $\mathrm{I}, \mathrm{n}=34$ & $\begin{array}{r}40,4 \\
\pm 1,21 \\
\end{array}$ & $\begin{array}{c}26,4 \\
\pm 0,68 \\
\end{array}$ & $\begin{array}{r}25,5 \\
\pm 0,64 \\
\end{array}$ & $\begin{array}{c}24,7 \\
\pm 0,62 \\
\end{array}$ & $\begin{array}{r}33,3 \\
\pm 1,01 \\
\end{array}$ & $\begin{array}{r}32,3 \\
\pm 0,96 \\
\end{array}$ & $\begin{array}{r}16,6 \\
\pm 0,49 \\
\end{array}$ \\
\hline II, $n=33$ & $\begin{array}{c}40,1 \\
\pm 1,00\end{array}$ & $\begin{array}{l}33,6^{\star * *} \\
\pm 1,35\end{array}$ & $\begin{array}{l}32,7^{* \star *} \\
\pm 1,27\end{array}$ & $\begin{array}{c}18,5 \\
\pm 0,72\end{array}$ & $\begin{array}{c}32,8 \\
\pm 0,57\end{array}$ & $\begin{array}{c}31,9 \\
\pm 0,68\end{array}$ & $\begin{array}{c}16,6 \\
\pm 0,29\end{array}$ \\
\hline III (контрольна, n=33) & $\begin{array}{c}40,3 \\
\pm 0,87\end{array}$ & $\begin{array}{c}29,5 \\
\pm 0,72\end{array}$ & $\begin{array}{c}28,8 \\
\pm 0,70\end{array}$ & $\begin{array}{c}24,1 \\
\pm 1,09\end{array}$ & $\begin{array}{c}33,3 \\
\pm 0,87\end{array}$ & $\begin{array}{c}32,5 \\
\pm 0,82 \\
\end{array}$ & $\begin{array}{c}17,0 \\
\pm 0,42\end{array}$ \\
\hline IV, $n=34$ & $\begin{array}{l}45,1^{* *} \\
\pm 1,33\end{array}$ & $\begin{array}{c}31,1 \\
\pm 1,09 \\
\end{array}$ & $\begin{array}{c}30,2 \\
\pm 1,07\end{array}$ & $\begin{array}{l}25,5^{\star * *} \\
\pm 1,06\end{array}$ & $\begin{array}{l}36,1^{* *} \\
\pm 0,81\end{array}$ & $\begin{array}{l}35,2^{* *} \\
\pm 0,77\end{array}$ & $\begin{array}{l}18,5^{\star *} \\
\pm 0,44\end{array}$ \\
\hline
\end{tabular}

Отже, найвищим добовим удоєм за повну лактацію дочок-первісток народжених у першу, другу та третю лактації корів-матерів становить близько 40 кг, тоді як у четверту - біля 45 кг молока.

Первістки II групи, отримані від матерів другої лактації мали найвищий показник удою в розрахунку на одну добу лактації. Так, у них цей показник в цілому за лактацію становив у середньому 33,6 кг, та 32,7 кг молока в перерахунку на 4 \%-не молоко, що було вище значення тварин аналогів I групи на 21,43 \% (P<0,001) на одну добу лактації та $22,02 \%(P<0,001)$ в перерахунку на $4 \%$-не молоко. В порівнянні з тваринами III (контрольної) групи вище на 12,20 $\%(P<0,01)$, та на $11,93 \%(P<0,01)$ в перерахунку на $4 \%$-не молоко, а показника первісток IV групи - на 7,44 \% і 7,65 \% відповідно в перерахунку на 4\%-не молоко.

Що стосується такого показника як коефіцієнт молочності, розрахований як кількість $4 \%$-ного молока що приходиться на 1 кг живої маси, то він у дослідних групах суттєво коливався - мінімальне значення 18,5 кг, а максимальне - 25,5 кг. Найнижче значення коефіцієнта молочності відмічалося у первісток II групи, який не перевищував 18,5 кг. Натомість у первісток I і III (контрольної) груп він знаходився на рівні відповідно 24,7 і 24,1 кг, що було вище показника тварин II групи на 25,1 \% (P<0,001) і 23,2 \% (P<0,001).

Найвищого свого значення набував коефіцієнт молочності у тварин IV групи і становив у першу лактацію у середньому 25,5 кг, що було більше показника корів II групи на 27,45\% (P<0,001).

Таким чином, коефіцієнт молочності у тварин I і III (контрольної) груп достатньо високий і знаходиться на одному рівні, тоді як у первісток II групи він мінімальний, а максимальний у тварин IV групи.

Аналізуючи функціональну активність лактуючого організму піддослідних первісток упродовж 305 діб лактації через показник кількості фізичного та в перерахунку на 4 \%не молоко отриманого на одну добу, слід зазначити, що вона була природно суттєво вищою у порівнянні з повною лактацією. Так, секреція молока на одну добу була високою і коливалася в межах 32,8-36,1 кг молока. Функціональна активність лактуючого організму у цей період була однаковою у тварин I і III (контрольної) групи і становила у середньому 33,3 кг. Найвища секреція молока була у первісток IV групи і становила у середньому 36,1 кг, що було вище показника корів II групи на 9,14\% (P<0,01). Стосовно кількості отриманого молока на одну добу в перерахунку на $4 \%$-не, то у тварин IV групи цей показник був також найвищим і становив 35,2 кг, що на 9,38 \% ( $\mathrm{P}<0,01)$ вище в порівнянні 3 тваринами II групи.

Порівнюючи, кількість молока отриманого на 1 кг живої маси в перерахунку на 4 \%-не молоко за 305 діб лактації, то вона була теж найвищою у тварин IV групи, i становила 18,5 кг, що в порівнянні з тваринами I і II групи було вище на 10,27 \% (P<0,01), а у порівнянні з тваринами III (контрольної) групи - на 8,11\% (Р<0,05).

Отже, первістки IV групи, отримані від матерів четвертої лактації, мають найвищу функціональну активність лактуючого організму, а тварини II групи, які отримані від корів-матерів другої лактації, - найнижчу.

Характеризуючи якісний склад молока корів-дочок голштинської породи у першу лактацію за інтенсивної технології експлуатації, отриманих від корів різного віку (табл. 3) необхідно відмітити, що він повністю відповідав породним 
особливостям, масова частка жиру в молоці була на високому рівні і коливалась в межах 3,80-3,84 \%. Тим не менше, якісний склад молока мав тенденцію спочатку деякого зростання до третьої лактації, а потім - незначного зниження до четвертої лактації. Так, у первісток III (контрольної) групи, отриманих від матерів третьої лактації, масова частка жиру в молоці була найвищою і становила 3,84 \%, що на 0,04 \% в абсолютному виразі було більше в порівнянні з тваринами । групи, у яких цей показник був найнижчим і становив 3,80 $\%$.

Таблиця 3

Якісні показники молока корів-дочок у першу лактацію

\begin{tabular}{|c|c|c|c|c|}
\hline \multirow{2}{*}{ Група тварин за віком у лактаціях } & \multicolumn{2}{|c|}{ Масова частка, \% } & \multicolumn{2}{|c|}{ Продукція, кг } \\
\hline & жир & білок & жиру & Білка \\
\hline $\mathrm{l}, \mathrm{n}=34$ & $3,80 \pm 0,043$ & $3,17 \pm 0,016$ & $570,43 \pm 14,637^{* * *}$ & $476,88 \pm 13,071$ \\
\hline II, $n=33$ & $3,83 \pm 0,019$ & $3,21 \pm 0,09$ & $427,89 \pm 15,448$ & $358,39 \pm 13,385$ \\
\hline III (контрольна, n=33) & $3,84 \pm 0,022$ & $3,18 \pm 0,023$ & $552,65 \pm 24,520^{\star \star *}$ & $458,68 \pm 21,617$ \\
\hline $\mathrm{IV}, \mathrm{n}=34$ & $3,82 \pm 0,014$ & $3,18 \pm 0,012$ & $581,57 \pm 23,846^{\star \star *}$ & $484,31 \pm 19,875^{\star \star \star}$ \\
\hline
\end{tabular}

Примітки: ${ }^{* *}-P<0,001$

У тварин IV групи цей показник знаходився на рівні у середньому 3,82 \%, що поступалося значенню корів III (контрольної) групи в абсолютному обчисленні на 0,02 \%, але було вище показника корів I групи на 0,02 \% в абсолютному виразі.

Стосовно масової частки білка в молоці, то вона була на рівні у середньому 3,17-3,21\%. У корів-дочок I групи, отриманих від матерів первісток, цей показник був найнижчим і становив 3,17\%, що на 0,04 \% в абсолютному виразі було нижче за показник тварин II групи, у яких він становив $3,21 \%$, що було максимальним у порівнянні з тваринамианалогами III (контрольної) і IV груп, у яких він був рівним і становив у середньому $3,18 \%$.

Найнижчим показником продукції молочного жиру характеризувалися тварини II групи, у яких він становив 427,89 кг, що було менше за показник тварин-аналогів I групи на 142,54 кг або 33,31\% (P<0,001), та на 124,76 кг або $29,16 \%(P<0,001)$ у порівнянні 3 тваринами III (контрольної) групи.

Порівняно найвищий показник молочного жиру мали тварини IV групи, у яких він становив у середньому 581,57 кг, що було вище на 26,43 \% (P<0,001), у порівнянні з тваринами II групи.

Отже, піддослідні первістки характеризуються високими показниками продукції молочного жиру, який в середньому становить 427,89-581,57 кг. Аналізуючи рівень продукції молочного білка первістками чотирьох дослідних груп слід зазначити, що найвищим показником відзначилися первістки IV групи, у яких він становив у середньому 484,31 кг, що було в 1,35 раза або на 26,00 \% (P<0,001) більше за показник тварин-аналогів II групи. Корови IV групи, у порівнянні з тваринами I і III (контрольної) груп, продукували молочного білка відповідно більше на 1,53 \% і 5,29 \%.

Таким чином, з віком у первісток, отриманих від матерів різного віку, відповідно до зміни удою, продукція молочного жиру та білка теж змінюється та досягає свого максимуму у первісток IV групи, отриманих від матерів четвертої лактації.

Висновки 1. Показник живої маси піддослідних тварин знаходиться в межах стандарту голштинської породи. Спостерігається чітка тенденція до зниження живої маси у піддослідних первісток залежно від віку їх матерів, що можна пояснити технологічним виснаженням організму тварин старших лактацій.

2. Тривалість лактаційного періоду тварин усіх піддослідних груп довша за значення референційованої лактації (305 діб). Найтривалішим продуктивний період був у тварин, народжених від первісток - 573 доби.

3. Показники молочної продуктивності знаходяться в прямій залежності від тривалості лактаційного періоду. Первістки, народжені від матерів четвертої лактації мають найвищий рівень молочної продуктивності - близько 11000 кг молока, що в середньому на 1000 кг більше, ніж значення цього показника у корів інших піддослідних груп.

4. Найвищим добовим удоєм (45 кг) характеризуються дочки-первістки, народжені від матерів четвертої лактації, що на 5 кг молока більше, ніж показник добового удою тварин інших піддослідних груп.

5. Усе поголів'я піддослідних тварин характеризується достаньмо високим показником продукції молочного жиру - в середньому 533,1 кг. Найвищого значення (581,5 кг) цей показник досягнув у первісток, отриманих від матерів четвертої лактації, а мінімальним значенням характеризувались первістки, народжені від корів у друге отелення.

\section{Список використаної літератури:}

1. Карамаев С.В. Соболева Н.В. Валитов Х.З. и др. Продуктивное долголетие коров чёрно-пёстрой породы и их помесей с голштинами в зависимости от способа содержания. Научные труды Брянской ГСХА. 2007. Вып. 1. С. 77 - 81.

2. Косырева М.С., Валитов Х.З., Соболева Н.В. и др. Влияние способа содержания коров на их продуктивное долголетие и интенсивность выбытия из стада. Известия Оренбургского государственного аграрного университета. 2007. № 3 (15). C. $149-151$.

3. Делян А.С., Ивашков А.И. Влияние возраста первого отёла на продуктивность и долголетие коров. Молочное и мясное скотоводство. 1999. № 8. С. $14-17$.

4. Овчинникова Л.Ю. Динамика показателей продуктивного долголетия коров. Молочное и мясное скотоводство. 2007. № 8. C. $21-22$.

5. Толманов А.А., Катмаков П.С., Гавриленко В.П. Продуктивное долголетие коров - важный селекционный признак. Зоотехния. 1998. № 11. С. 2 - 3.

6. Донник И.М, Шкуратова И.М., Соколова О. В. и др. Оптимизация показателей резистентности и обменных процесСов - основа повышения продуктивного долголетия коров. Ветеринария Кубани. 2010. № 3. С. 9 - 12. 
7. Мымрин В.С. Влияние средовых и генетических фракторов на продуктивное долголетие коров. Современные проблемы диагностики, лечения и профилактики инфекционных болезней животных: сб. науч. тр. ведущих учёных России, СНГ и др. стран : Екатеринбург : Уральское изд-во. 2008. Вып. 2. С. $338-342$.

8. Підпала Т.В. Генезис породного перетворення в популяції червоної степової худоби : монографія. Миколаїв : МДАУ, 2005. 312 c.

9. Полупан Ю.П., Коваль Т.П. Успадковуваність молочної продуктивності корів української червоної молочної породи. Розведення і генетика тварин. 2005. Вип. 39. С. 158-165.

10. Гиль М.І. Системний генетичний аналіз полігенно зумовлених ознак худоби молочних порід : монографія. Миколаїв : МДАУ, 2008. 478 с.

11. Хмельничий Л.М., Салогуб А.М., Вечорка В.В., Гаврилюк О.І. Вплив генотипових та паратипових чинників на ознаки молочної продуктивності корів різних порід. Вісник Сумського національного аграрного університету: серія "Тваринництво". 2014. Вип. 2/1(24). С. 87-91.

12. Селекція сільськогосподарських тварин / Ю. Ф. Мельник, В. П. Коваленко, А. М. Угнівенко та ін.; за заг. ред. Ю. Ф. Мельника, В. П. Коваленка та А. М. Угнівенка. Київ, 2008. 445 с.

13. Зайцев Є.М. Особливості успадкування ознак молочної продуктивності дочками корів голштинської породи. Вісник аграрної науки Причорномор'я. 2017. Вип. 4. С. 150-157.

14. Прохоренко П.Н. Методы создания высокопродуктивных молочных стад. Зоотехния. 2001. № 11. С. 2 - 6.

\section{References:}

1. Karamaev, S.V. Soboleva, N.V. Valitov, H.Z., 2007. Produktivnoe dolgoletie korov chjorno-pjostroj porody i ih pomesej s golshtinami v zavisimosti ot sposoba soderzhanija [Productive longevity of cows of black-motley breed and their crossbreeds with holstein depending on the method of keeping]. Scientific works of the Bryansk State Agricultural Academy, issue 1, pp. 77-81.

2. Kosyreva, M.S., Valitov, H.Z., Soboleva, N.V., 2007. Vlijanie sposoba soderzhanija korov na ih produktivnoe dolgoletie i intensivnost' vybytija iz stada [The influence of the method of keeping cows on their productive longevity and the rate of exit from the herd]. News of the Orenburg State Agrarian University, issue 3 (15). pp. 149-151.

3. Deljan, A.S., Ivashkov, A.I., 1999. Vlijanie vozrasta pervogo otjola na produktivnost' i dolgoletie korov [The influence of the age of the first calving on the productivity and longevity of cows]. Dairy and beef cattle breeding, issue 8. S. 14-17.

4. Ovchinnikova, L., 2007. Dinamika pokazatelej produktivnogo dolgoletija korov [Dynamics of indicators of productive longevity of cows]. Dairy and beef cattle breeding, issue 8. pp. 21-22.

5. Tolmanov, A. A., Katmakov, P. S., Gavrilenko, V. P., 1998. Produktivnoe dolgoletie korov - vazhnyj selekcionnyj priznak [Productive longevity of cows is an important breeding trait]. Livestock, issue 11. pp. 2-3.

6. Donnik, I.M, Shkuratova, I.M., Sokolova, O.V., 2010. Optimizacija pokazatelej rezistentnosti i obmennyh processov - osnova povyshenija produktivnogo dolgoletija korov [Optimization of indicators of resistance and metabolic processes is the basis for increasing the productive longevity of cows]. Veterinary medicine of Kuban, issue 3, pp. 9-12.

7. Mymrin, V.S.,2008. Vlijanie sredovyh i geneticheskih faktorov na produktivnoe dolgoletie korov [The influence of environmental and genetic factors on the productive longevity of cows]. Current problems in the diagnosis, treatment and prevention of infectious animal diseases: a collection of scientific papers by leading scientists of Russia : Yekaterinburg : Ural Publishing House, issue 2. pp. 338-342.

8. Pidpala, T.V., 2005. Henezys porodnoho peretvorennia v populiatsii chervonoi stepovoi khudoby [The genesis of pedigree reincarnation in the population of chervonovo steppe thinness]. Mikolaiv: MDAU.

9. Polupan, Y.P., Koval, T.P., 2005. Uspadkovuvanist molochnoi produktyvnosti koriv ukrainskoi chervonoi molochnoi porody [Success of dairy productivity of Ukrainian red dairy breed]. Breeding and genetics of animals, issue 39, pp. 158-165.

10. Hyl, M. I., 2008. Systemnyi henetychnyi analiz polihenno zumovlenykh oznak khudoby molochnykh porid [Systematic genetic analysis of polygenically conditioned traits of dairy cattle]. Mykolaiv: MDAU.

11. Khmelnychyi, L.M., Salohub, A.M., Vechorka, V.V., Havryliuk, O.I., 2014. Vplyv henotypovykh ta paratypovykh chynnykiv na oznaky molochnoi produktyvnosti koriv riznykh porid [nfluence of genotypic and paratype factors on signs of dairy productivity of cows of different breeds]. Bulletin of Sumy National Agrarian University: series Livestock, issue 2/1 (24), pp. 87-91.

12. Melnyk, Y. F. ed., 2008. Selektsiia silskohospodarskykh tvaryn [Selection of farm animals]. Kyiv.

13. Zaitsev, Y.M., 2017. Osoblyvosti uspadkuvannia linak molochnoi produktyvnosti dochkamy koriv holshtynskoi porody [Features of inheritance of signs of dairy productivity by daughters of cows of Holstein breed]. Bulletin of Agrarian Science of the Black Sea, issue 4, pp. 150-157.

14. Prohorenko, P.N., 2001. Metody sozdanija vysokoproduktivnyh molochnyh stad [Methods of creating high-performance dairy herds]. Livestock, issue 11, pp. 2-6.

\section{Kapshuk N.O.}

\section{Realization of the productive potential of milk production primary production in the industrial complex}

The article reflects the results of research on the manifestation of the genetic potential of dairy productivity of Holstein firstborn born from mothers in the first, second, third and fourth lactation, in conditions with full compliance with the rules of humane treatment and veterinary and sanitary norms on livestock stock breeding Union "of Sinelnikov district of Dnipropetrovsk region. The productive qualities of the experimental animals were characterized by live weight ( $\mathrm{kg}$ ), lactation duration (days), milk yield over the entire lactation period, and 305 days lactation $(\mathrm{kg})$ physical and $4 \%$ milk. Thus, the duration of the lactation period of the animals of all experimental groups is longer than the value of the reference lactation (305 days). The longest productive period was in animals 
born to first-born animals 573 days. The functional activity of the organism of the experimental animals, four experimental groups was determined by the highest daily milk yield for full lactation $(\mathrm{kg})$, the amount of physical and in terms of $4 \%$ milk received per day for lactation and for 305 days of lactation ( $\mathrm{kg}$ ), and also the amount of milk received per $1 \mathrm{~kg}$ of live weight in terms of $4 \%$ milk for full and 305 days of lactation ( $\mathrm{kg})$. Thus, the highest daily milk yield $(45 \mathrm{~kg})$ is characterized by first-born daughters born of mothers of the fourth lactation, which is $5 \mathrm{~kg}$ more milk than the daily milk yield of animals of other experimental groups. Characterizing the qualitative milk composition of daughters of Holstein cows in the first lactation, obtained from cows of different ages, it should be noted that it completely corresponded to the breed characteristics, so the mass fraction of fat and protein was at a high level fluctuated within 3.80-3.84\% and 3.17-3.21\% respectively. The index of production of milk fat and protein in them was $427.89-581.57 \mathrm{~kg}$ and $358.39-484.31 \mathrm{~kg}$ respectively. It was established that by indicators of full lactation yield and in terms of 305 days, duration of productive period, functional activity of the organism and qualitative characteristics of dairy products, the firstborn born of the mother of the fourth lactation were more productive and stable. Instead, first-borns from second-lactation cows showed the lowest values of the above indicators.

Key words: firstborn, live weight, lactation, fat, protein.

Дата надходження до редакції: 09.11.2019 р. 